\title{
An Interpretation of the Chinese Architectural Design Elements in Qing Dynasty's Costumes
}

\author{
$\mathrm{Na} \mathrm{Li}$ \\ Huanghe Science and Technology College \\ Zhengzhou, China \\ e-mail: 109960521@qq.com
}

\begin{abstract}
This article makes a systematical analysis of the Chinese architectural elements designed in Qing Dynasty court dress in the perspective of historical research and the appearance, aiming at making a depth interpretation of the blending of Chinese architectural design elements and the Qing Dynasty costumes. The purpose of this interpretation is to show the long history and rich cultural heritage of the Chinese nation's costume as well as building architecture, so as to find a new way of narrative art for the modern fashion design.
\end{abstract}

Keywords-Qing Dynasty; court; architecture; costume design

\section{INTRODUCTION}

Mentioned architecture, brick and beams would come to mind, which have a close relationship with human's living space. In the history of clothing design, costume and architecture are the most commonly produced together ones. Follow the historical context of development we can find that no matter in which historical period costumes and architecture are the most direct response to intelligence information of the society. Hegel-master aesthetics in German defined the relationship of the two - "Fashion is flowing architecture."

China has a long history and rich cultural heritage, which created a splendid dress culture and architectural art. Traced back to the Qing Dynasty in China, court dress reflects the impact of architecture on costume culture. Whether it is gorgeous imperial court dress, or harsh robes shape, both has a bond with traditional Chinese architecture. This paper focuses on the traditional Chinese architectural design elements in the Qing dynasty costume combining with modern fashion design, in order to explore commonalities and artistic value of the two with the purpose to make the past serve present.

\section{THE CHARACTERISTIC OF THE QING DYNASTY PALACE DRESS}

Costume culture is a direct reflection of dynasties, thus it is an important starting point in the study of costume history. After the Qing Amy broke into Shanhaiguan, Manchu and Han culture came into a period of blending, the most outstanding performance was reflected in the shape of court dress.

Qing Dynasty is a specific historical period in the history of clothing, but it is also the heyday of ancient clothing development before the new era clothing arrival. Court costumes made the biggest change during this period. Although the royal were non-Han, but they retained the original costume tradition mostly and combined Man and Han ethnic cultures. Therefore, the most significant feature of the court dress in the Qing Dynasty is the integration of Manchu clothing. Men changed clothes, shaved and built braid. Through coercive means, the reform in the national consciousness was prompted.

In the course of the study, the author conducts a topdown style of analysis with a overall classification.

\section{A. Crown Cap}

Due to the harsh Costume Qing regime, crown cap has become an important factor in the Qing government officials to distinguish between levels. The types of court crown are many and harassment complex, including the crown and official hat and so on. The crown of an Emperor is a hat, which is divided into two types -summer crown and winter crown, according to the season. Between them, summer crown is the most typical one; cap body has a double tower shape.

The official hat whether for officials or emperors, basically consists of bong race, cap-wai, top beads, tubes and branch of Ling. The overall shape is conical. Bong race is the edge of the cap around the body, common appeared in official hat worn by the officials, and is produced in different materials according to climate change. The red cap tassel is the cap-wai made by red silk, the top of beads of crowns are also called Dingzi. According to the grade of emperors and officers, colors and materials as well as number of Dingzi are made with strict requirements. Below the top bead, a tube is equipped in order to insert Ling branch. HuaLing of crowns behind the cap top is made of peacock tail, whose circle number represents the official grade level. Meanwhile, there are strict rules in the Qing Dynasty costumes; different costume needs different crown cap to match. 


\section{B. Dressing}

The dressing rules are stringent in Qing court; different levels of official have different dressing rules, one can not arbitrarily change the attire which includes vestment, court dress and common dress and so on.

Gun fu is vestment worn by the Qing emperor while holding worship ceremony. The contour Gunfu is like other clothing with straight body type, tiled in trapezoid which consists of the shirt attached by lower part.

Court dress is the most solemn dress in costumes of the Qing court including Mangpao, Bugua and Duanzhao, which are usually worn on important occasions, and embroidered with twelve patterns. The Shape of court dress is a gown by adding an up and down parts together; its sleeve cuffs like arrows, Dajin and shoulder with batch collar, waist decorated with pockets.

Common dress is mainly Guahepao, the same shape with the shirt and lower part connected; most of which are round neck collar or stand collar, the upper part of her gown reaching the feet is connected by Pankou (they are made of thread).

Throughout the Qing court clothing styles for both men and women, they are unified with barrel body and tight sleeves. Jianxiu and Piling are particularly notable features in the Qing Dynasty court dress. The main difference between the grades is to see the top of beads, as well as ornamentation of Mangpao.

\section{Footwear}

Shoes in Qing Dynasty especially women's shoes are with the most prominent features. "Flag shoes" is a highheeled shoe with a wooden bottom; about $10 \mathrm{~cm}$ height heel is fitted in the middle of the sole, looks like a flowerpot, it is also known as the "saucers." Uppers of shoes are embroidered cloth in decorative patterns.

\section{Accessories}

The officials wearing robes in the Qing Dynasty are required to wear beads. The total number of beads is 108 , lined with three strings of beads, while one bunch of which on the one side and two strings other side. Men and women wear beads differently, two strings on the left were male, and two strings on the right were for women. There are a bunch of beads hanging in the back

Cloud shoulder and Xiapei as shoulder decorations for women, are part of the Qing Dynasty dress for Mingfu (a woman in ancient China who was given a title or rank by the emperor, usually is the mother or wife of a official). These decorations with harassment decorative patterns and revealing her husband grade can reflect the typical characteristics of court costumes in Qing Dynasty.
III. TYPICAL STYLE ELEMENTS OF CHINESE ARCHITECTURE - TAKING THE FORBIDDEN CITY, TEMPLE OF HEAVEN, FOR EXAMPLE

Under the feudal monarchy, in addition to strict control of clothing by the rulers, the building also reflects this imperial dignity. Among the many ancient buildings, The Imperial Palace is our largest, most complete ancient buildings as well as the world's largest palace. As a building with most Chinese characteristics and Oriental style, it has also become the world's first impression of China. The Imperial Palace, also known as the Forbidden City, is the palace in Ming and Qing dynasties, now it carries typical meaning in the study of traditional Chinese architecture.

Temple of Heaven is the place where emperors in Ming and Qing dynasties prayed for good harvest every year. The Qing rulers are nomads who place great emphasis on worship ceremony. Nearly a thousand years of Chinese cultural essence are reflected in the Forbidden City and the Temple building. Through analysis, we can summarize the characteristics of Chinese traditional architectural style as follows:

Special roof shapes: The most typical feature of Chinese architecture is colorful pieces of roof tile. There are dozens of different styles of roof shapes in the Forbidden City only. But whether with profound eaves in Forbidden City, or roof tilt wing with angle, or conical roofs in Temple of Heaven, they are able to highlight the unique charm of traditional Chinese architecture.

Exquisite decorative patterns: in classical Chinese style architecture, Intricate carved beams under traditional arts exudes a unique charm of the ancient incense, of which the palace building is the most representative ones. Pictures designing in Palace architectural are more about dragon, phoenix, turtle, lion, etc, and attach emphasis on symmetry.

Warm vibrant colors: the commonly used colors in Chinese traditional architecture are high red, yellow or purity of color. Seemingly simple colors contain full meaning in Chinese traditional architecture. Such as three-storeyed eaves in Qiniandian Palace uses respectively cyan, yellow, and green glazed tiles to symbolize heaven, earth and everything on the earth.

A variety of roof shapes in Traditional architecture, cornices wing corner, painting, Zhu column and Jinding, internal and external doors and garden decoration scene, all of those fully reflects the ancient Chinese traditional architectural charm.

\section{ChINESE ARCHITECTURAL STYLE ElEMENTS OF QING Costume Under APPEARANCE PERSPECTIVE}

\section{A. The Chinese Architectural Design Elements in Crown Cap}

Compared from the appearance, the summer crown and the roof shape of Qiniandian in Temple of Heaven are most similar to each other among these similar shapes of crown cap and the roof. 
For the triple-domed palace of Qiniandian, its top is covered with up-green, middle-yellow, and down-green glass, it means the sky, the earth, and every other thing; later changed to a uniform of blue tile and Golden top, named "Qiniandian." Formally, the red cap tassel summer crown looks like the upper roof of Qiniandian, the top part has a top bead decoration. The summer crown was decorated with the Golden Buddha on its eaves side, which are very similar with the plaque shapes in Qiniandian.

The Imperial Vault of Heaven was a single roof style, like the official's hat in the Qing Dynasty.

Through the comparison between the roof of the traditional Chinese ancient buildings and official's costume, it is not difficult to find that the two have much in common. It also helps us to make a clear view of application of the ancient architectural style elements in the palace costume in Qing Dynasty.

\section{B. Architectural Style Elements in Chinese Clothing}

Pankou and knocker: Pankou first appeared in Manchu costumes, now is widely used in modern Chinese clothing, evolved into a typical symbol of traditional Chinese elements. Mentioned Pankou, no matter in either coiling method or what shape, we would have a common visual impression of its symmetry. In the building, following this feature, we can easily find that knocker with a symmetry styling elements is inextricably linked with Pankou. Knocker consists of two parts: base and pendant, base is usually made of decorative patterns, it has become an integral part of the Chinese architectural culture. The opening part of clothing is called front fly, Pankou is positioned right here for the opening and closing the garment. Knocker is located in the opening and closing place for the connection. Therefore, these two are similar in both shape and function.

Pleated skirt and roof tiles: pleat is shaped stereotypes waves, usually used in lower part of the Qing palace costumes, forming a natural bump undulating rhythm. Roof tiles are the material used in Chinese building, arranged side by side in an arched style.

Dressing trim and architectural trim: as a typical feature in the Qing Dynasty costume, roll trim inlay is a wide lace for decoration. In the Qing Dynasty palace dressing, whether ceremonial robe or common dress, both will be decorated with trim, located in the collar, sleeves, and hem skirts, but the pattern may vary. In Chinese traditional architecture, this kind of decoration is picture carving, often with two parties appeared in a continuous strip between the edge of the door frame and layers.

Dressing color and architectural color: the most common color used in Qing Dynasty palace costumes is yellow, red and blue and so on. From traditional Chinese architecture, we still can extract these primary colors.

Dressing patterns and architectural design: the Qing palace dress design patterns include patterns of twelve chapters, dragons, and waterlines, moiré and so on. These patterns can also be found in buildings.
In addition to a similar appearance on the outside, in fact, we also find that some of the symbolism used both in dressing and architecture according to historical research. For example, nine, five- these two figures symbolize elegance. In ancient times, the emperor of a country also is known as the Ninth of respect. Qing emperor's robes usually were embroidered with eight dragons, plus a dragon on the skirt equal right night. But when you look back or surfaces alone, there are five dragons. In the previous analysis, we know that the number of Chinese palace architecture level has a certain symbolic; stairs and railings are in multiples of nine, to show symbolism of cloud nine. In addition to stairs and railings, doornails on the doors have a strict system. Forbidden City, south, north, west doors all three were knocked with nine rows and nine lists doornails, in order to symbolize the sky.

\section{INSPIRATION OF ARCHITECTURAL DESIGN ELEMENTS IN MODERN FASHION DESIGN}

In fact, back in the 1970s and 1980s, designer Pierre Cardin already designed typical costume on the use of Chinese traditional architectural elements. Including domestic designer Huxiaodan takes clothing as a medium, through clothing styles designing to reproduce the unique charm of the Forbidden City. At the senior custom conference of Giorgio Armani in 2009, a series of stunning dressing show with Chinese ancient buildings and cornices knocker style shows a strong oriental flavor.

The relationship between dressing and architecture not only exists in ancient feudal period, chemical reactions between these two also will take place in the future. Although both material media are different, but they all belong to the field of design arts, can resonate with each other, then to obtain identity. Therefore, the study of the relationship between ancient Chinese costumes and architecture can guide the modern fashion design.

Under the trend of global information synchronization, national boundaries of modern architecture become less and less obvious. Under the increasingly unfavorable condition that architecture provides for costume design inspiration, the study of ancient buildings will gradually deep, in order to provide more efficient design material for the modern fashion design, and truly make the past serve the present.

We also expect that this kind of research can be more diverse for designers to seek inspiration elements through cross-border cooperation. Not only architectural elements can be used as clothing, apparel features can also be expressed as architectural creativity. It is hopeful that the contemporary fashion design or architectural design can form an extension of the exchange and integration with more art and design.

\section{CONCLUSION}

In this paper, the author takes Chinese architectural design elements reflected in the Qing palace costumes as the main object of study, makes a comprehensive and systematical description to the shape, decoration, colors and applications. Through research, we can conclude that, in the 
same historical period, dressing and architectural design is with typical identity. Architectural art and dressing art is intertwined, they are the national carrier of culture, conveys the spiritual world of the creator to us. Aiming at analysis the blend point of palace costumes in Qing Dynasty and traditional Chinese architectural style, so that it can be applied to modern fashion design.

The reason we put the dressing and architecture as a symbolic interpretation of language fragments is to find that they all have the same sociological significance. First of all, both of which have certain functionality, can protect humans; secondly, from the material point of view, both symbolize wealth; thirdly, from the creation of the media perspective, both needs to be designed through the material as an intermediary, finally, the three-dimensional shape can be accomplished. In culture, both reflect the popular culture and the message at the moment; they convey a sense of human aesthetic constantly updated and developed.

With advances in technology, dressing will become a highly technical intersect disciplines; we will continue indepth practice after this study, sought to apply research results to make a perfect fusion between clothing art and architectural art.

\section{REFERENCES}

[1] Bao Mingxin et al. The Tree like Chinese Clothing [M], Shanghai: Shanghai Bookstore Publishing House, 2004.

[2] Yuan Ze. Chinese Clothing History [M], Beijing: China Textile Press, 2005.

[3] Feng Zemin et al. Tutorial of Western Clothing Development History [M]. Beijing: China Textile Press, 2007.

[4] Hua Mei. Chinese Clothing History [M]. Tianjin: Tianjin People's Fine Arts Publishing House, 1995.

[5] Li Li. Officers System and Costumes in the Qing Dynasty [M]. Liaoning: Liaoning Ethnic Publishing House, 2009.

[6] Zhang Qiong. The Court Dress in the Qing Dynasty [M]. Shanghai: Shanghai Science and Technology Press, 2006.

[7] Tang Deliang. Large and Elaborate Roof: China Construction $\bullet$ Roof [M]. Liaoning: Liaoning Ethnic Publishing House, 2006.

[8] Wang Wensi. Chinese Architecture [M]. Jilin, Times Art Publishing House, 2009. 